\title{
Mediation Effects of Internal Financial Decisions and Company Performance on the Relationship of Macroeconomic Factors and Market Reactions
}

\author{
Indarto \\ Universitas Semarang \\ indarto@usm.ac.id \\ Djoko Santoso \\ Universitas Semarang \\ djoko_hw@usm.ac.id
}

\begin{abstract}
This study examines the effect of macroeconomic factors on investor reactions in the capital market with internal financial decisions and company performance as the intervening variables. Previous studies examined only the effect of macroeconomic factors on direct market reactions. The sample of this research are manufacturing companies listed on the Indonesia Stock Exchange. Structural Equation Modeling (SEM) was tested using SmartPLS. This study concludes that financial decisions and company performance are not the intervening variables between macroeconomic factors and market reactions. Macroeconomic factors do not affect the company's internal financial decisions and company performance but the market reaction. Meanwhile, the company's internal financial decisions have no effect on the company's performance and market reaction. The company's performance affects the market reaction. The results of this study prove that investors are very concerned about macroeconomic factors in making investment decisions. The dynamics of macroeconomic factors directly influence investment decisions in the capital market.
\end{abstract}

Keywords: macroeconomic factors, market reaction, internal financial decisions, business performance.

\section{INTRODUCTION}

Investors need an estimate of the results of their placement of funds, especially the placement of high-risk funds in the capital market. Investors can use technical analysis and fundamental analysis in predicting the risks and returns of their investments in the capital market. Technical analysis is based on the assumption that future stock prices can be predicted using past price movement patterns. Meanwhile, if using fundamental analysis, investors can 
predict stock price movements by observing various fundamental factors, both macro fundamentals and micro fundamentals. Micro fundamental factors are company-specific conditions such as financial statements, capital structure, asset structure, profitability, and others, while macro fundamental factors can be in the form of inflation, interest rates, exchange rates, social conditions, politics, and other factors that can affect performance.

The study of market reactions to changes in economic factors has been carried out by many researchers. Williamson (2014) states that one of the factors that influence market reactions is macroeconomic factors. Macroeconomic indicators such as inflation, interest rates, exchange rates, money supply, economic growth, balance of payments deficit and others indicate whether the economy is sluggish or in a state of excitement. Companies cannot control these macroeconomic factors, but can predict and anticipate them in each of their strategic planning and investment planning. Macroeconomic factors will always be considered in every company's internal financial decisions to achieve the goals that have been set (Mokhova \& Marek, 2013). Macroeconomic factors can significantly have a positive or negative effect on stock market performance (Kumar, 2013), but some researchers find evidence that changes in macroeconomic factors do not have any effect on returns, especially in efficient markets. According to the efficient market hypothesis, investors will not be able to earn abnormal profits because all information about economic changes will immediately reflect stock prices in the stock market (Naik \& Padhi, 2012).

One of the macroeconomic factors that has become the center of attention is inflation. Inflation is a tendency to increase general prices continuously. Inflation makes the business world face uncertainty, making it difficult to formulate plans for business activities. The uncertainty caused by inflation will have a negative impact on production, investment and in determining product prices. Another important macroeconomic factor is the interest rate or 
BI Rate. The BI Rate is one of the quantitative monetary policy instruments used by Bank Indonesia to control inflation and stabilize the Rupiah exchange rate. The BI Rate will be raised or lowered to improve the health of the economy.

A healthy economy is a prerequisite for the business sector to grow and develop. Starting in 2015, Indonesia's inflation rate has always been at a low level. Bank Indonesia then responded to the low inflation by lowering the benchmark interest rate (BI Rate) continuously from 2016 to 2018. The exchange rate of the Rupiah against foreign currencies, especially against the US Dollar also has a significant effect on Indonesia's economic conditions, because it will on inflation, investor and public confidence.

Previous studies on market reactions have mostly studied the direct influence between macroeconomic factors and market reactions, so that there is an inconsistency of the influence of macroeconomic factors with market reactions. Pal and Garg (2019) found that monetary policy and other macroeconomic policies implemented to stabilize the economy affected the market reaction. This finding is reinforced by research by Pareira (2010) which proves that the movement of macroeconomic factors is a strong consideration for investors in making investment decisions. Pareira proves that there is a negative relationship between inflation and stock prices. Kipkorir and Tarus (2012) found a negative relationship between inflation and market reaction which was surrogated by stock prices. Other studies show different findings that macroeconomic indicator factors have no effect on market reactions. Kurihara (2006) who examined the relationship between macroeconomic variables and stock prices in Japan, found that the domestic interest rate did not significantly affect stock price changes in Japan, but the exchange rate had a positive and significant effect on stock prices in Japan. The results of this study support the research of Gupta et al. (2000), who found evidence that there is no strong relationship between exchange rates and stock prices. Stock prices are actually more affected 
by the trend of interest rates during the period, where interest rates have a negative and significant effect on stock prices. Megaravalli and Sampagnaro's research (2018) proves that there is a causal relationship between the exchange rate and the stock markets of India, China and Japan.

This study tries to include internal financial decision variables as intervening variables to fill the gaps in various previous research results. This internal financial decision variable is appointed on the basis that these macroeconomic factors are highly considered by companies or issuers that are part of the capital market in making their internal financial decisions. Internal financial decisions in principle include funding decisions, investment decisions and dividend decisions. Every company's internal financial decisions must be aimed at achieving high company performance. The company's performance will always be a concern and observation of investors in determining their investment decisions. This research was conducted on the basis that the very dynamic economic situation definitely has an impact on the financial decisions and financial performance of each company. Investors will also respond to any economic dynamics in investing in the capital market that appears as a market reaction.

\section{LITERATURE REVIEW}

The overall economic performance can be seen from the development of indicator factors such as Gross Domestic Product (GDP), inflation, interest rates, money supply, exchange rates and balance of payments deficit (Williamson, 2014). These macroeconomic factors are a signal for the business world whether the business prospects are bright or not. Macroeconomic factors are external factors that cannot be controlled or controlled by the company. Macroeconomic factors are influenced by world economic conditions and government policies. Government policies that are carried out to make the economy healthy are 
fiscal policy, monetary policy and real sector policy. Every change in macroeconomic factors will have consequences for the financing and revenue side of the company. Companies cannot control macroeconomic factors, but can predict and anticipate them in every strategic planning and investment planning. Macroeconomic factors will always be considered in every company's internal financial decisions to achieve predetermined performance (Mokhova \& Marek, 2013).

The influence of macroeconomic factors on market reactions is well explained by Pal and Garg (2019). According to Pal and Garg the market, the stock market is one of the intermediary institutions that play an important role in the effectiveness of monetary policy and other macroeconomic policies. Investors really consider the movement of macroeconomic factors in making investment decisions. In this study, macroeconomic variables are surrogated by indicators of interest rates, the rupiah exchange rate against the dollar and the inflation rate.

This study also uses signaling theory which states that the management has more information about the future of the company, so that a publicly listed company must transparently convey the company's condition to investors. One signal of management policy is dividend policy. The policy is expected to give a signal to investors (as external parties) about the company's prospects and provide usefulness to investors as consideration in the investment decision-making process. If the content of information is considered important by investors, then management can use the policy as a signal about the company's value that can be achieved, seen from its effect on stock returns (Scott, 2015).

In general, there are two approaches that are often used by investors to assess and analyze stocks in the capital market, namely fundamental analysis and technical analysis (Bodie et al., 2005). Fundamental analysis is a historical analysis of the company's internal conditions as well as estimating the factors that influence future stock prices. The basis of this analysis is the stock value which is strongly influenced by the performance of the issuer's company. If the 
performance of the public company is in good condition, then the company's stock price can be expected to reflect this strength as indicated by an increase in stock prices.

Internal financial decisions are related to determining the source of funds to be used, determining the optimal funding balance, and the company using sources of funds from within the company or will take funds from outside the company. Internal financial decisions are very important for companies, because they involve obtaining sources of funds for company operations. This policy will affect the capital structure and leverage factors of the company, both operating leverage and financial leverage. Capital structure is an important element in determining the success of the company by using a combination of debt and equity (Abor, 2005). The wrong decision in optimizing the financial structure will cause financial difficulties for the company and lead to bankruptcy (Eriotis, 2007), because the use of debt will create financial risks for the company. The selection of a capital structure that reflects financial resources is very important in determining the company's performance. Internal financial decisions also include corporate earnings management decisions. Whether the profits will be divided as dividends or retained to be reinvested in the company and so do they as to maximize the company's price.

Company performance is an achievement achieved by a company in its operations. A company can grow internally or externally. Most of the company's growth occurs by internal expansion, but corporate growth can also occur because it is facilitated by the stock exchange (Selvam et.al, 2016). In terms of financial management, company performance can be measured using various proxies such as profitability, sales growth and firm value.

Market reaction is the response of market participants, especially investors, to an event or events or certain conditions. Market reaction can be measured by stock price movements, bid-ask price spreads, trading volume and abnormal returns. In this study, market reactions are 
intended as investor responses to changes in macroeconomic variables, company micro fundamental factors and company policies or decisions.

Investors are not only important to look at the company's external factors, but also have to pay attention to the company's internal financial decisions, namely funding decisions and investment decisions. Companies that are developing will allocate most of their funds to finance their investment activities, so companies choose not to distribute dividends or pay bond interest. The increasing rate of inflation causes the company's investment risk to increase in securities such as stocks and bonds. High interest rates will be a burden for the company due to the increasing cost of capital, especially for companies that have a high debt ratio. The exchange rate of the Rupiah against foreign currencies, especially the US Dollar, also influences the company's funding decisions and investment decisions, because exchange rate volatility will increase the risk in financing and investment. The cash flow received will greatly affect changes in the rupiah exchange rate against foreign currencies (Fabozzy, 2010).

Daniel's study (2018) examines the relationship between macroeconomics and the performance of companies listed on the Ghana Stock Exchange (GSE). ROE and ROA were chosen as proxies for company performance with the independent variables being company sales growth, total assets, leverage, dividend payments, and the main macroeconomic variables (GDP, inflation, interest, and exchange rates). Daniel's research uses panel data that runs from 2007 to 2015 . The test results find that inflation has a negative effect on ROA while interest rates have a negative effect on ROE. The study suggests Ghanaian companies to develop policies to improve their performance by taking into account fluctuations in macroeconomic indicators. The research of Issah and Antwi (2017) also strengthens the evidence that economic factors affect company performance. Demir (2007) states that macroeconomic uncertainty as surrogated by the exchange rate and inflation has a significant negative effect on the 
profitability of manufacturing companies. Ameer's (2012) study shows a significant relationship between nominal interest rates and firm performance. The results of research by Abaidoo and Kwenin (2013) conclude that there is a relationship between macroeconomic conditions and company profit growth. The study also concludes that expected inflation has a positive effect on company performance and profitability.

Internal financial decisions are related to funding decisions whether to use sources of funds to purchase company assets in the form of foreign capital (short term and long term) or in the form of own capital. All internal financial decisions are aimed at optimizing the value of the company. According to Fama and French (1998), one financial decision taken will affect other financial decisions and have an impact on firm value, therefore funding and investment decisions must be combined as well as possible. The combination will maximize the value of the company, and ultimately provide increased wealth prosperity to shareholders. Research by Chai and Zhang (2011) found that the capital market reacts negatively and significantly to DER information of a company. Capital investment is one of the main aspects of investment in addition to determining the composition of assets. Decisions on the allocation of capital into investment proposals should be evaluated and linked to the risks and expected returns. According to signaling theory, investment spending gives a positive signal about the company's growth in the future, so that it can increase stock prices which are used as indicators of company value.

Companies must make the right decisions for funding, investment and dividends to achieve high performance and corporate value. Investors will observe a company's financial decisions, especially those related to dividends, because dividends are part of the income of shareholders. Internal financial decisions related to earnings and dividends are of great interest to investors. Investors will pay close attention to the company's choice to distribute profits as 
dividends or hold profits to finance investments in the future. The decision to distribute dividends will be responded positively by investors. Research by Berezinets et al (2017) proves that good or bad announcements about dividends always cause negative reactions in the Russian stock market, while in India bad news about dividends is responded negatively by the stock market in India.

The company's performance in this study is surrogated by return on equity (ROE) and return on assets (ROA). Return on equity (ROE) is a ratio that measures the effectiveness of the company in generating profits by utilizing the capital owned by the company. This ratio is a measure of the success of company managers in maximizing the rate of return to shareholders. The higher this ratio, the better because it provides a greater rate of return to shareholders. Information on increasing ROE will be accepted by the market as optimism for investors in making decisions to buy shares. This makes the demand for shares increase so that the price will rise. This statement is reinforced by the results of Nurfadillah (2011) who found that ROE had a significant positive effect on stock prices.

Return on assets (ROA) is a ratio that reflects the company's ability to obtain net profit after tax from the total assets used for company operations. This ratio is used to measure the efficiency level of the company in utilizing its assets in the company's operational activities. The higher this ratio indicates that the company is more effective in utilizing assets to generate net profit after tax. Information on increasing ROA will be accepted by the market as a good signal that will provide positive input for investors in making decisions to buy shares. This makes the demand for shares increase so that the price will rise. This statement is reinforced by the results of Yusi (2010) who found that ROA has a positive and significant effect on stock prices. 


\section{METHODS}

The population of this study are all manufacturing companies listed on the Indonesia Stock Exchange (IDX). The sampling technique used in this research is purposive sampling or sample selection with certain objectives or criteria. The sample criteria for this study are 1) manufacturing companies listed on the Stock Exchange; 2) have sufficient data in accordance with the data needed by this study. SEM (Structural Equation Model) using Partial Least Square (PLS) was the technique used for analyzing data. PLS model was chosen with consideration of data limitations and data distribution that is not normally distributed.

This study examines the structural model of the influence of macroeconomic factors on market reactions. Macroeconomic factors (FM) are surrogated by inflation, interest rates and the exchange rate of the rupiah against the US dollar. Market reaction (MR) is surrogated by stock returns and total activity volume. Internal financial decisions (IFD) are surrogated by funding decisions and dividend decisions. Company performance (BP) as a proxy for ROE and ROA as mediating variables.

\section{RESULTS AND DISCUSSION}

The results of the model test show that the indicators are INF, ROA, DPR, and TVA, so that all indicators have loadings above 0.7. Each variable has an AVE value above 0.5 (valid), and has a Cronbach's alpha value above 0.6 and a composite reliability value above 0.7 , so it can be concluded that the variables used are valid and reliable (see table 1). The structural model is presented in figure 1.

Table 1 Path Coefficients

\begin{tabular}{lccccc}
\hline & $\begin{array}{c}\text { Original } \\
\text { Sample }\end{array}$ & Sample Mean & $\begin{array}{c}\text { Standard } \\
\text { Deviation } \\
(\text { STDEV) }\end{array}$ & T Statistics & P Values \\
\hline MF $\rightarrow$ IFD & 0,071 & 0,059 & 0,105 & 0,674 & 0,501 \\
MF $\rightarrow$ BP & $-0,057$ & $-0,061$ & 0,087 & 0,651 & 0,515
\end{tabular}




\begin{tabular}{lccccc}
\hline & $\begin{array}{c}\text { Original } \\
\text { Sample }\end{array}$ & Sample Mean & $\begin{array}{c}\text { Standard } \\
\text { Deviation } \\
\text { (STDEV) }\end{array}$ & T Statistics & P Values \\
\hline $\mathrm{MF} \rightarrow$ MR & 0,371 & 0,386 & 0,091 & 4,086 & 0,000 \\
IFD $\rightarrow$ BP & 0,562 & 0,529 & 0,165 & 3,411 & 0,001 \\
IFD $\rightarrow$ MR & 0,0119 & 0,127 & 0,158 & 0,750 & 0,454 \\
BP $\rightarrow$ MR & 0,064 & 0,082 & 0,154 & 0,414 & 0,679 \\
\hline
\end{tabular}

Source: Data processed, 2020

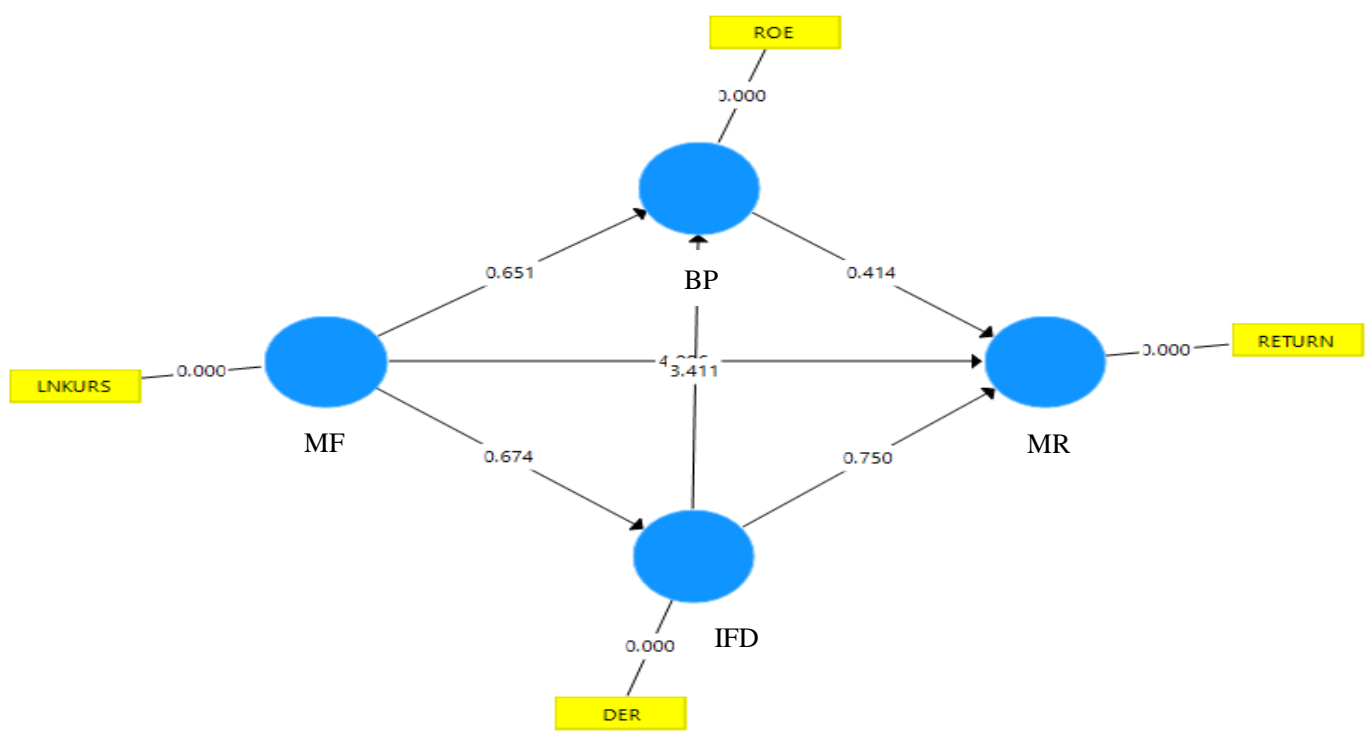

Figure 1 Inner Model Test Results

From the indirect effects matrix presented in table 2, it can be concluded that there are direct effects.

Table 2 Output Indirect Effects Bootstrap SmartPLS

\begin{tabular}{|c|c|c|c|c|c|}
\hline & $\begin{array}{l}\text { Original } \\
\text { Sample }\end{array}$ & Sample Mean & $\begin{array}{l}\text { Standard } \\
\text { Deviation } \\
\text { (STDEV) }\end{array}$ & T Statistics & P Values \\
\hline \multicolumn{6}{|l|}{$\mathrm{MF} \rightarrow \mathrm{IFD}$} \\
\hline $\mathrm{MF} \rightarrow \mathrm{BP}$ & 0,040 & 0,028 & 0,059 & 0,667 & 0,505 \\
\hline $\mathrm{MF} \rightarrow$ & 0,007 & 0,000 & 0,030 & 0,242 & 0,809 \\
\hline $\begin{array}{l}\text { MR } \\
\text { IFD } \rightarrow \text { BP }\end{array}$ & & & & & \\
\hline $\begin{array}{l}\mathrm{IFD} \rightarrow \mathrm{MR} \\
\mathrm{BP} \rightarrow \\
\mathrm{MR}\end{array}$ & 0,036 & 0,037 & 0,094 & 0,383 & 0,702 \\
\hline
\end{tabular}

Source: Data processed, 2020 
The total effect matrix shows the total effect value that occurs in the relationship between each construct with a cut-off value at the t-statistical value $>$ t-table $=1.96$ and the probability value $(\mathrm{P}$-value) $<0.05$. As presented, the total value of the relationship between the constructs. Based on data processing that has been carried out using the Smart PLS program, it can be seen that the adjusted R-Square value for the market reaction variable is 0.136 , which indicates that the market reaction variable can be explained by macroeconomic factors, internal financial decisions and company performance of $13.6 \%$.

Table 3 Total effects Bootstrap SmartPLS

\begin{tabular}{lccccc}
\hline & $\begin{array}{c}\text { Original } \\
\text { Sample }\end{array}$ & Sample Mean & $\begin{array}{c}\text { Standard } \\
\text { Deviation } \\
\text { (STDEV) }\end{array}$ & T Statistics & P Values \\
\hline MF $\rightarrow$ IFD & 0,071 & 0,059 & 0,105 & 0,674 & 0,501 \\
MF $\rightarrow$ BP & $-0,017$ & $-0,033$ & 0,110 & 0,153 & 0,878 \\
MF $\rightarrow$ MR & 0,378 & 0,0389 & 0,091 & 4,175 & 0,000 \\
IFD $\rightarrow$ BP & 0,562 & 0,529 & 0,165 & 3,411 & 0,001 \\
IFD $\rightarrow$ MR & 0,155 & 0,164 & 0,100 & 1,550 & 0,122 \\
BP $\rightarrow$ MR & 0,064 & 0,082 & 0,154 & 0,414 & 0,679 \\
\hline
\end{tabular}

Source: Data processed, 2020

The results of hypothesis testing indicate that macroeconomic factors did not significantly influence the company's internal financial decisions. The ineffectiveness of macroeconomic indicators on internal financial decisions is due to the time lag between changes in macroeconomic indicators and their real impact. Changes in macroeconomic indicators do not always directly have a significant impact on the company's financial condition because the company's financial performance depends on the ability of management to manage company finances. Effective corporate policies will result in good financial performance even though economic factors are very dynamic.

The test also indicates that macroeconomic factors significantly influence the market reaction. The result strengthens the findings of Yuliana (2012) and Evendy and Isynuwardhana 
(2015) which stated that macro variables have a significant effect on market reactions as indicated by changes in stock returns. Research by Megaravalli and Sampagnaro (2018) found that inflation and exchange rates, which are important macroeconomic indicators, have a significant effect on market reactions. Investors in the capital market will respond quickly to macroeconomic changes. Investors will carefully calculate the positive or negative impact of each change in macroeconomic indicators on the company's performance in the next few years and then make a decision to buy or sell the shares in question. Therefore, stock prices adjust more quickly than the company's performance to changes in macroeconomic variables.

This study arrives at the result that macroeconomic factors measured using indicators of inflation, interest rates, and exchange rates did not affect the company's performance as surrogated by ROE, ROI, and sales growth. The explanation for this finding is that macroeconomic factors have become an important consideration in corporate decision making. In other words, every possible change in macroeconomic factors has been anticipated in advance in planning the company's goals, so that when a change in macroeconomic factors occurs, it does not have a significant impact on the achievement of the goals that have been set and does not significantly affect the company's performance. The results of this study support the research results of Khan et al. (2012) which states that external factors, namely exchange rates, interest rates, and inflation have no significant effect on changes in company performance. The results of this study also strengthen those of Evendy and Isynuwardhana (2015) which concluded that macroeconomic factors of inflation, interest rates and the Rupiah exchange rate against the US dollar have no effect on company performance.

If we look at the phenomenon of Indonesia's macroeconomic factors during 2015-2018, the government has managed to maintain economic stability well. The inflation rate in the 20152018 period can be reduced by around 3 percent, so that the interest rate is also conducive to the 
business world. The rupiah exchange rate against the US dollar did fluctuate so that it reached a new balance, but the government managed to control these fluctuations, so that the business world was able to maintain its performance.

The study results in internal financial decisions have a positive and significant effect on company performance. The results of the study strengthen the research of Hidayat (2009) which states that internal financial decisions affect the company's performance as surrogated by ROA. Funding decisions, investment decisions and dividend decisions are directed to create optimal financial performance.

Furthermore, internal financial decisions is found as have no effect on market reactions. The results of this study agree with the results of Surahman's research (2016). Based on the phenomena occurring in Indonesia, the market is more responsive to changes in macroeconomic factors and events that are expected to have a significant impact on the business world.

The company's performance has no significant effect on the market reaction. These results strengthen the results of Azizah (2014) which concludes that the company's financial performance with ROA proxy has no effect on stock returns. The company's performance is publicly published by the company through the company's financial statements that reflect the company's financial performance. Investors use the company's performance as a guide in determining their investment. Investors will choose a company that has good financial performance because investors want to get a profitable return on the investment that has been invested. In this study, the company's performance does not affect the market reaction.

Explaination of this finding is that the financial performance as reflected in the company's financial statements is information that can be observed and analyzed by investors before making investment decisions. Financial performance in financial statements is not information that requires investors to react quickly, so that financial performance does not affect 
the market reaction. The market reacts more to economic and political issues that are expected to have an impact on the security of investors' investments. The explanation from Arleni (2011) in his research which also finds that the company's performance does not affect the market reaction is the management factor.

The results of testing the indirect effects relationship to examine the intermediation effect of company internal financial decisions and company performance in relation to macroeconomic factors with market reactions conclude that internal financial decisions and company

\section{CONCLUSIONS AND IMPLICATIONS}

Macroeconomic factors do not affect the company's internal financial decisions and company performance, but affect the market reaction. While the company's internal financial decisions do not affect the market reaction but affect the company's performance. The company's performance has no effect on the market reaction. Internal and corporate financial decisions and company performance were not able to mediate the relationship between macroeconomic factors and market reactions. These results prove that macroeconomic dynamics are highly considered by the market. Investors use macroeconomic information to make investment decisions. However, investors are very careful in analyzing the dynamics of macroeconomic factors.

The limitation of this study is that the observation period is too short and thus further research is expected to increase the observation period.

\section{ACKNOWLEDGEMENT}

This research was funded by the Research and Service Institute of the University of Semarang. 


\section{REFERENCES}

Abor, J.Y. (2005). The effect of capital structure on profitability: An empirical analysis of listed firms in Ghana, The Journal of Risk Finance, 6(5), 438-445.

Abaidoo, R., Kwenin, D.O. (2013). Corporate profit growth, macroeconomic expectations and fiscal policy volatility. International Journal of Economics and Finance, 5(8), 25-38.

Ameer, R., (2012). Macroeconomic factors and initial public offerings (IPOs) in Malaysia. Asian Academy of Management Journal of Accounting and Finance, 8(1), 41-67.

Bhamra, H.S., Fisher, A.J., Kuehn, L.A. (2011). Monetary policy and corporate default. Journal of Monetary Economics, 58(5), 480-494.

Cai, J., Zhang, Zhe. (2011). Leverage change, debt overhang, and stock prices, Journal of Corporate Finance, 17(3), 391-402.

Eriotis, N., Vasiliou, D. (2007). How firm characteristics affect capital structure: An empirical study, Managerial Finance, 33(5), 321-331.

Fama and French. (1998). Value versus growth: the international evidence. Journal of Finance, 53, 1975-1999.

Gay, R.D. (2016). Effect of macroeconomic variables on stock market returns for four emerging economies: Brazil, Russia, India, and China. International Business \& Economics Research Journal, 7(3), 1-8.

Gupta, J. P., Alain, C., Fran, S. (2000). The causality between interest rate, exchange rate and stock price in emerging market: the case of Jakarta Stock Exchange. European Financial Management Journal Graduate School of Business, 1-22.

Irina, B., Ilina, Y., Smirnov, M., Bulatova, L. (2017). How does stock market react to dividend surprises? Evidence from emerging markets of India and Russia. Journal of AsiaPacific Business, 8(3), 153-179.

Khan, Z., Khan, S., Rukh, L., Imdadullah, ur Rehman, W. (2012). Impact of interest rate, exchange rate, and inflation on stock return of KSE 100 index. International Journal of Economics and Research, 142-155.

Kipkorir, K.J. and Tarus, D.K. (2012). Macroeconomic determinants of stock market development in emerging markets: evidence from Kenya, Research Journal of Finance and Accounting, 3(5), 57-67.

Kumar, R. (2013). The effect of macroeconomic factor on Indian stock market performance: A factor analysis approach. IOSR Journal of Economics and Finance (IOSR-JER), 1(3), $14-21$.

Kurihara (2006). The relationship between exchange rate and stock prices during the quantitative easing policy in Japan, International Journal of Business, 11, 375-386. 
Kweku, D. (2018). The impact of macroeconomic factors on firm performance. University of Ghana, http://ugspace.ug.edu.gh

Lewellen, J.W. (2000). Predictability of stock returns: Theory and evidence. School of Business Administration. University of Rochester, New York.

Naik, P.K., Padhi, P. (2012). The impact of macroeconomic fundamentals on stock prices revisited: Evidence from Indian data. Eurasian Journal of Business and Economic, 5(10), 25-44.

Nuryasman, M.J.S. (2017). Moderation effect of exchange rate to signaling theory validity in Indonesia stock exchange, Business and Management Studies, 3(1), 80-89.

Pal, S., Garg, A.K. (2019). Macroeconomic surprises and stock market responses-A study on Indian stock market. Cogent Economics and Finance, 7(1), 1-31.

Puspitaningtyas, Z. (2019). Empirical evidence of market reactions based on signaling theory in Indonesia stock exchange. Investment Management and Financial Innovations, 16(2), 66-77.

da Silva, P., Luiz, Harris, R.E. (2010). Sailing through the global financial storm: Brazil's recent experience with monetary and macro prudential policies to lean against the financial cycle and deal with systemic risks, Working Paper No. 290, Central Bank of Brazil.

Scott, W. R. (2015). Financial Accounting Theory (7th edition). Toronto: Pearson Education Canada, Inc.

Zare, R., Kiafar, H., Kanani, M. A., \& Farzanfar, F. (2013). Dividend policy from the signaling perspective and its effects on information asymmetry among management and investors. Research Journal of Applied Sciences, Engineering and Technology, 6(21), 4090-4097. 